\title{
ANALISIS FAKTOR-FAKTOR YANG MEMPENGARUHI PEMBENTUKAN HARGA BERAS DI INDONESIA
}

\author{
Desi Setiawati, Edmon Daris* dan Mudatsir Najamuddin
}

\begin{abstract}
ABSTRAK
Hasil pengujian diperoleh nilai adjusted R2 sebesar 90,76\%. Hasil tersebut menunjukkan bahwa pembentukan harga beras di Indonesia dapat dijelaskan oleh variabel bebas yang digunakan dalam model yaitu produksi beras, konsumsi beras, harga beras impor, dan nilai tukar rupiah terhadap dollar Amerika sebesar 90,76\%. Sedangkan sisanya yaitu 9,24\% dijelaskan oleh variabel lain di luar model penelitian ini. Hasil pengujian secara bersama-sama menunjukkan variabel produksi beras domestik, konsumsi beras domestik, harga beras impor, dan nilai tukar rupiah terhadap dollar Amerika berpengaruh terhadap pembentukan harga beras di Indonesia dengan nilai $\mathrm{F}$ hitung $(42,77)$ lebih besar dari $\mathrm{F}$ tabel $(3,18)$ atau nilai probabilitas $0,000000<0,05$. Hasil pengujian secara parsial diketahui bahwa variabel produksi beras domestik, konsumsi beras domestik, dan nilai tukar rupiah terhadap dollar Amerika masing-masing berpengaruh secara signifikan terhadap variabel harga beras domestik pada $\alpha=0,05$, sedangkan variabel harga beras impor tidak berpengaruh secara signifikan terhadap variabel harga beras domestik.
\end{abstract}

Kata Kunci: beras, harga, produksi, konsumsi, impor, nilai tukar

\section{ABSTRACT}

The test results obtained a value of adjusted Rsquare of $90.76 \%$. These results indicate that the formation of rice prices in Indonesia can be explained by the independent variables used in the model is the production of rice, rice consumption, the price of imported rice, and the exchange rate of rupiah against the US dollar by $90.76 \%$. While the remaining $9.24 \%$ is explained by other variables outside this research model. The joined test results indicate variables of domestic rice production, domestic rice consumption, the price of imported rice, and the exchange rate against the US dollar affect the formation of prices of rice in Indonesia with a value of $F(42.77)$ is greater than $F$ table (3.18) or probability value is $0.000000<0.05$. Partial test results found that the variable domestic rice production, domestic rice consumption, and the rupiah against the US dollar respectively significantly affect the domestic rice price variables at $\alpha=0.05$, whereas the variable import prices did not significantly affect variable domestic rice prices.

Keywords: rice, price, production, consumption, import, exchange rate 


\section{PENDAHULUAN}

Pangan merupakan kebutuhan dasar manusia yang paling utama dan pemenuhannya merupakan bagian dari hak asasi manusia yang dijamin di dalam Undang-Undang Dasar Negara Republik Indonesia Tahun 1945 sebagai komponen dasar untuk mewujudkan sumber daya manusia yang berkualitas. Berdasarkan Undang-Undang No 18 Tahun 2012 tentang Pangan yang telah disahkan melalui sidang pleno Dewan Perwakilan Rakyat Republik Indonesia pada tanggal 18 Oktober 2012, pangan adalah segala sesuatu yang berasal dari sumber hayati produk pertanian, perkebunan, kehutanan, perikanan, dan peternakan, baik yang diolah maupun tidak diolah yang diperuntukkan sebagai makanan atau minuman bagi konsumsi manusia, termasuk bahan tambahan pangan, bahan baku pangan, dan bahan lainnya yang digunakan dalam proses penyiapan, pengolahan, dan pembuatan makanan dan minuman (Pujiasmanto, 2013:1).

Beras merupakan kebutuhan pangan pokok bagi lebih dari $90 \%$ penduduk Indonesia. Konsumsi beras per kapita mempunyai kecenderungan mengalami penurunan yakni dari $115,60 \mathrm{~kg} / \mathrm{kapita} / \mathrm{tahun}$ pada tahun 1993 menjadi 93,18 $\mathrm{kg} / \mathrm{kapita} /$ tahun pada tahun 2008 (Susenas, 1993 dan 2008). Produksi beras dalam negeri dari tahun ke tahun terus meningkat, walaupun mempunyai kecenderungan laju pertumbuhannya melandai. Di sisi lain, pertumbuhan penduduk Indonesia melaju dengan cepat, yakni 1,27\% per tahun pada periode tahun 2005-2010 (BPS, 2009).

Liberalisasi perdagangan untuk pangan dapat membuat harga pangan tidak stabil, terutama karena perubahan atau berkurangnya cadangan yang dimiliki masing-masing negara. Dengan berkurangnya stok, maka intervensi ke pasar, khususnya negara eksportir akan berkurang, sehingga stok pangan global akan berkurang atau menipis. Karena keterbatasan stok, maka pasar dunia menjadi kurang mampu menahan (buffer) dalam penyesuaian terhadap perubahan konsumsi dan perubahan produksi (Sawit, 2007: 40).

Perdagangan pangan global dapat berkontribusi terhadap ketahanan pangan suatu pangan dengan cara seperti: (i) mengisi kekurangan antara kebutuhan untuk konsumsi dengan kemampuan produksi; (ii) dapat mengurangi gejolak (variability) pasokan pangan di suatu negara; (iii) meningkatkan pertumbuhan ekonomi; (iv) penggunaan sumber daya di dunia akan lebih efisien karena pangan dihasilkan di wilayah yang mempunyai keunggulan komparatif; dan (v) memungkinkan berproduksi secara global di wilayah yang lebih ekonomis sesuai dengan sumber dayanya (Sawit, 2007: 37).

\section{METODE PENELITIAN}

\section{Ruang Lingkup dan Waktu Penelitian}

Ruang lingkup dalam penelitian ini terbatas pada mempelajari dan menganalisis faktor-faktor yang mempengaruhi pembentukan harga beras melalui pendekatan teori permintaan dan penawaran. Prasurvey dilakukan pada bulan November 2014 selama satu bulan penuh, dengan mengumpulkan berbagai informasi dan literatur terkait dengan penelitian. Survey dilakukan pada bulan Desember 2014 sampai dengan bulan Maret 2015 dengan melakukan riset terhadap data yang telah terkumpul.

\section{Jenis dan Sumber Data}

Data yang digunakan dalam penelitian ini berupa data sekunder yang berbentuk data time series. Semua data diperoleh dari Badan Pusat Statistik, Departemen Pertanian, Kementerian Perdagangan, dan Bank Indonesia serta literatur-literatur dan situssitus yang terkait dengan penelitian ini yang 
menyediakan kebutuhan data yang diperlukan dalam penelitian.

\section{Metode Pengumpulan Data}

Metode pengumpulan data dalam penelitian ini, peneliti mengambil data dokumentasi.

\section{Metode Pengolahan dan Analisis Data Model Regresi \\ Dalam pengolahan dan analisis data digunakan analisis kualitatif dan kuantitatif, data yang diperoleh diolah kemudian dilakukan analisis dengan metode regresi linier berganda. Model persamaan regresi linier berganda untuk pembentukan harga beras adalah sebagai berikut:}

$\mathrm{Y}=\mathrm{b} 0+\mathrm{b} 1 \mathrm{X} 1+\mathrm{b} 2 \mathrm{X} 2+\mathrm{b} 3 \mathrm{X} 3+\mathrm{b} 4 \mathrm{X} 4+\mathrm{e}$

Keterangan :

$\mathrm{Y}=$ Harga beras domestik (dalam rupiah per ton)

$b 0=$ Konstanta (nilai $\mathrm{Y}$ pada saat $\mathrm{X}$ sama dengan nol)

$b 1, b 2, b 3, b 4=$ Koefisien regresi parsial

$\mathrm{X} 1=$ Produksi beras (dalam ton)

$\mathrm{X} 2=$ Konsumsi beras (dalam ton)

$\mathrm{X} 3$ = Harga beras impor (dalam rupiah per ton)

$\mathrm{X} 4$ = Nilai tukar rupiah (dalam rupiah per dollar Amerika Serikat)

et $=$ variabel gangguan

Uji Penyimpangan Asumsi Klasik

Uji asumsi klasik dilakukan untuk menghasilkan estimator yang linier tidak bias dengan varian yang minimum (Best Linier Unbiased Estimator $=$ BLUE), uji penyimpangan asumsi klasik perlu dilakukan, dengan meliputi:

1. Uji Normalitas, Langkah-langkah pengujian normalitas data sebagai berikut:

Hipotesis:

H0: Model Normal
Ha: Model Tidak Normal

Jika probabilitas $>0,05 \Rightarrow$ signifikan, $\mathrm{H} 0$ diterima

Jika probabilitas $<0,05 \quad$ H0 ditolak

2. Uji Multikolinieritas, Ada beberapa metode untuk mendeteksi masalah multikolinieritas dalam suatu model regresi, salah satunya adalah dengan menguji koefisien korelasi (r) antar variabel independen. Sebagai aturan main yang kasar (rule of thumb), jika koefisien korelasi cukup tinggi yakni di atas 0,85 maka diduga ada multikolinieritas dalam model. Sebaliknya jika koefisien korelasi relatif rendah maka kita duga model tidak mengandung unsur multikolinieritas (Widarjono, 2013:104).

3. Uji Heteroskedastisitas, metode deteksi masalah heteroskedastisitas bisa dilakukan secara informal maupun formal. Penelitian ini menggunakan metode formal yakni dengan metode white. Uji ini mengasumsikan bahwa varian error merupakan fungsi yang mempunyai hubungan dengan variabel bebas, kuadrat masing-masig variabel bebas dan interaksi antar variabel bebas. Dimana keputusan ada tidaknya heteroskedastisitas bisa dilihat dari besar kecilnya nilai Probabilitas ChiSquare.

H0 : Tidak ada heteroskedastisitas

$\mathrm{HO}$ : Ada heteroskedastisitas

Dengan tingkat signifikan $(\alpha)$ sebesar 5\% dan menggunakan Probabilitas Chi-Square, maka kriteria Uji White adalah:

Jika Probabilitas Chi-Square > 0,05 maka $\mathrm{H} 0$ diterima

Jika Probabilitas Chi-Square $<0,05$ maka $\mathrm{H} 0$ ditolak 
4. Uji Autokorelasi, Salah satu uji autokorelasi yang digunakan dalam penelitian ini adalah metode BreuschGodfrey atau yang lebih dikenal dengan Uji Lagrange Multiplier (LM). Pada Uji Lagrange Multiplier:

H0 : Tidak ada autokorelasi

H1 : Ada autokorelasi

Dengan tingkat signifikan $(\alpha)$ sebesar 5\% dan menggunakan distribusi ChiSquare, maka:

Jika Prob Chi-Square < 0,05 maka H0 ditolak

Jika Prob Chi-Square > 0,05 maka H0 diterima

Uji Kesesuaian (Test of Goodness of Fit)

1. Uji Koefisien Determinasi (R2), Nilai koefisien determinasi (R2) ini mencerminkan seberapa besar variasi dari variabel terikat $\mathrm{Y}$ dapat diterangkan oleh variabel bebas $\mathrm{X}$ (Nachrowi, 2006:20). Nilai koefisien determinasi terletak antara 0 dan 1 (0 $\leq \mathrm{R} 2 \leq 1$ ). Semakin angkanya mendekati 1 maka semakin baik garis regresi karena mampu menjelaskan data aktualnya. Semakin mendekati angka nol maka garis regresi yang dimiliki kurang baik (Widarjono, 2013:26).

2. Uji Hipotesis Secara Simultan (Uji F), Uji F bertujuan untuk mengetahui apakah variabel independen yang terdapat dalam model secara bersama-sama berpengaruh nyata terhadap variabel dependen. Hipotesis uji $\mathrm{F}: \mathrm{H} 0: \beta 1=\beta 2=\ldots=$ $\beta \mathrm{k}=0$ atau variasi perubahan nilai variabel independen tidak dapat menjelaskan variasi perubahan nilai variabel dependen.

$\mathrm{H} 1$ : paling tidak satu dari $\beta \mathrm{k} \neq 0$ atau minimal ada satu nilai parameter dugaan yang tidak sama dengan nol atau variasi perubahan nilai variabel independen dapat menjelaskan variasi perubahan nilai variabel dependen. Kemudian dilakukan pengujian dimana Fhitung dari hasil analisis dibandingkan dengan Ftabel, yakni: Jika Fhitung > Ftabel maka H0 ditolak

Jika Fhitung < Ftabel maka H0 diterima.

3. Uji Hipotesis Secara Parsial (Uji t), $\mathrm{H} 0: b i=0$, artinya bahwa masingmasing variabel bebas (independent) dalam model tidak berpengaruh nyata terhadap variabel tak bebas (dependent) pada tingkat kepercayaan tertentu.

$\mathrm{H} 1: b i \neq 0$, artinya bahwa masingmasing variabel bebas (independent) dalam model berpengaruh nyata terhadap variabel tak bebas (dependent) pada tingkat kepercayaan tertentu. Kemudian dilakukan pengujian dimana thitung dari hasil anal sis dibandingkan dengan ttabel, yakni:

Jika thitung > ttabel maka $\mathrm{H} 0$ ditolak Jika thitung < ttabel maka HO diterima

\section{HASIL DAN PEMBAHASAN}

\section{Identifikasi Faktor-faktor yang Mempengaruhi Pembentukan Harga Beras di Indonesia.}

Data yang digunakan dalam penelitian ini adalah deret waktu (time series) selama 18 tahun, yang dimulai dari tahun 1996 sampai dengan tahun 2013. Sebelum membuat model regresi linier berganda, terlebih dahulu dilakukan uji asumsi klasik yang meliputi uji normalitas, uji multikolinieritas, uji heteroskedastisitas, dan uji autokorelasi. Uji asumsi klasik tersebut bertujuan agar 
kesimpulan dari model regresi tersebut tidak bias.

1. Hasil Uji Penyimpangan Asumsi Klasik Uji penyimpangan asumsi klasik bertujuan untuk mengetahui masalah yang biasa terjadi pada metode Ordinary Least Square (OLS). Jika model regresi yang digunakan bebas dari masalahmasalah normalitas, heteroskedastisitas dan autokorelasi sehingga dapat diketahui bersifat BLUE (Best Linier Unbias Estimator) yang berarti tidak ada gangguan serius terhadap asumsi klasik dalam metode kuadrat kecil tunggal (OLS).

\section{Uji Normalitas}

Tabel 1. Histogram-Normalitas test

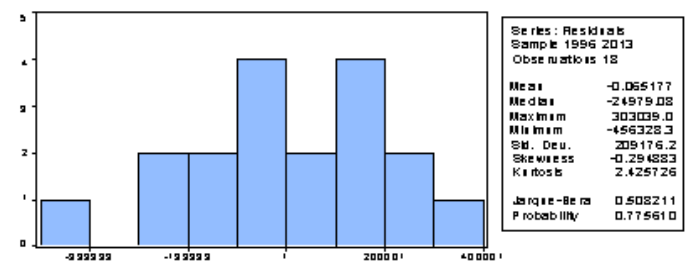

Sumber: data sekunder diolah,2015.

3. Uji Multikolinieritas

Tabel 2. Hasil uji multikolinieritas

Sumber: Data sekunder diolah, 2015.

Terlihat dari tabel nilai korelasi variabel independen (yaitu X1, X2, X3, dan $\mathrm{X} 4$ ) tertinggi mencapai 0.949337 yaitu nilai korelasi antara X1 dan X2. Karena nilai $0.949337>0,85$ maka diputuskan terdapat multikolinieritas.

\section{Uji Heteroskedastisitas}

Tabel 3. Hasil uji heteroskedastisitas Sumber: Data sekunder diolah, 2015.

\begin{tabular}{|llll|}
$\mid$ He teroskedasticity Test: White & & \\
\hline F-statistic & 0.685149 & Prob. F(4,13) & 0.6148 \\
\hline Obs*R-squared & 3.133980 & Prob. Chi-Square(4) & 0.5357 \\
Scaled explained SS & 1.165317 & Prob. Chi-Square(4) & 0.8838
\end{tabular}

Berdasarkan tabel menunjukkan bahwa Obs*R-square sebesar 3.133980 dengan nilai Prob. Chi-Square sebesar 0.5357. Karena nilai Probabilitas ChiSquare 0.5357 lebih besar dari derajat kesalahan 5\% $(\alpha=0,05)$, maka $\mathrm{H0}$ diterima sehingga dapat disimpulkan bahwa dalam model ini tidak terdapat heteroskedastisitas. Hal ini menginformasikan model OLS yang dilakukan terbebas dari masalah heteroskedastisitas.

\section{Uji Autokorelasi}

Tabel 4. Hasil uji autokorelasi

\begin{tabular}{|lll|l|}
$\mid$ Breusch-Godfrey Serial Correlation LM Test: & \\
\hline F-statistic & 0.549566 & Prob. F(2,11) & 0.5923 \\
Obs*R-squared & 1.635188 & Prob. Chi-Square(2) & 0.4415
\end{tabular}

Sumber: Data sekunder diolah, 2015

Chi-Square sebesar 0.4415. Karena nilai Prob. Chi-Square lebih besar dari pada $\alpha=0,05$ maka dapat diberikan penjelasan bahwa model penelitin ini terbebas dari permasalahan autokorelasi.

\section{Perhitungan Regresi Berganda Faktor- faktor yang Mempengaruhi}

\begin{tabular}{|c|c|cc|c|} 
& $\mathrm{X} 1$ & $\mathrm{X} 2$ & $\mathrm{X} 3$ & $\mathrm{X} 4$ \\
\hline $\mathrm{X} 1$ & 1.000000 & 0.949337 & 0.114063 & 0.852335 \\
\hline $\mathrm{X} 2$ & 0.949337 & 1.000000 & 0.228226 & 0.756872 \\
\hline $\mathrm{X} 3$ & 0.114063 & 0.228226 & 1.000000 & -0.057889 \\
\hline $\mathrm{X} 4$ & 0.852335 & 0.756872 & -0.057889 & 1.000000
\end{tabular}

\section{Pembentukan Harga Beras di Indonesia.}

Tabel 5. Hasil perhitungan regresi berganda. Sumber: Data sekunder diolah, 2015.

\begin{tabular}{|c|c|c|c|c|c|}
\hline $\begin{array}{l}\text { No } \\
1 .\end{array}$ & $\begin{array}{c}\text { Faktor } \\
\text { Produksi Beras }\left(\mathrm{X}_{1}\right)\end{array}$ & $\begin{array}{c}\text { Koefisien } \\
\text { Regresi } \\
-0.167597\end{array}$ & $\begin{array}{c}\text { Thtung } \\
-3.077184\end{array}$ & $\begin{array}{l}\text { Prob. } \\
0.0088\end{array}$ & $\begin{array}{c}\text { Std. } \\
\text { Error } \\
0.054465\end{array}$ \\
\hline 2. & Konsumsi Beras $\left(\mathrm{X}_{2}\right)$ & 0.312172 & 6.210970 & 0.0000 & 0.050261 \\
\hline 3. & Harga Beras Impor $\left(\mathrm{X}_{3}\right)$ & 0.010192 & 0.119409 & 0.9068 & 0.085354 \\
\hline \multirow[t]{2}{*}{4.} & Nilai Tukar Rupiah ( $\left.\mathrm{X}_{t}\right)$ & 68.00357 & 1.953459 & 0.0726 & 34.81188 \\
\hline & Konstanta & -267463.0 & -0.382702 & 0.7081 & 698880.6 \\
\hline
\end{tabular}


Dari tabel diatas diketahui persamaan regresi untuk faktor-faktor yang mempengaruhi pembentukan harga beras adalah :

$\mathrm{Y}=-267463-0.167597 \mathrm{X} 1+0.312172 \mathrm{X} 2$ $+0.010192 \mathrm{X} 3+68.003570 \mathrm{X} 4$

Dari persamaan regresi tersebut, diperoleh nilai konstanta sebesar -267463. Hal ini diartikan bahwa apabila semua variabel bebas dianggap konstan atau tidak mengalami perubahan maka akan terjadi penurunan harga beras domestik sebesar Rp 267.463,-/ton atau setara dengan Rp 267,-/kg. Untuk produksi beras (X1) dihasilkan koefisien negatif sebesar -0.167597 . Tanda negatif ini menunjukkan hubungan yang berlawanan antara produksi beras domestik dengan harga beras domestik. Dengan kata lain jika ada kenaikan produksi beras domestik sebesar satu satuan maka terjadi penurunan harga beras domestik sebesar 0.167597. Misalnya terjadi kenaikan produksi beras domestik dari 45 juta ton menjadi 46 juta ton (naik 1 juta ton), maka akan terjadi penurunan harga beras domestik sebesar Rp 167.597,-/ton atau setara dengan Rp 168,-/kg. Untuk X2 hingga X4 bernilai positif, artinya setiap kenaikan produksi diikuti oleh kenaikan harga.

\section{Hasil Uji Statistik}

1. Hasil Uji Koefisien Determinasi (R2)

Tabel 6. Hasil uji R2

\begin{tabular}{|cc|c|}
\hline $\mathbf{N} 0$ & Keterangan & Nibi \\
\hline 1 & $\mathrm{R}^{2}$ & 0.929378 \\
\hline 2 & $\mathrm{R}^{2}$ yang dise suaikan & 0.907648
\end{tabular}

Sumber: Data sekunder diolah

Nilai koefisien determinasi yang disesuaikan adalah sebesar 0.907648 yang berarti bahwa hanya 90,76 persen variasi atau perubahan dalam harga beras bisa dijelaskan oleh seluruh variabel bebas yang diduga berpengaruh. Sisanya sebesar 9,24 persen dijelaskan oleh faktor lain di luar penelitian ini.

2. Hasil Uji Hipotesis Secara Simultan (Uji F)

Tabel 7. Uji F

\begin{tabular}{|l|cc|c|c|} 
Model & Df & F $_{\text {ble: }}$ & $\mathbf{F}_{\text {butd }}$ & Prob. \\
Regresi & $(4 ; 13)$ & 42.76965 & 3,18 & 0.000000
\end{tabular}

Sumber: Data sekunder diolah, 2015

Hasil perhitungan uji $\mathrm{F}$ yang diperoleh nilai Fhitung sebesar 42.76965 lebih besar dari Ftabel $(3,18)$ dengan tingkat kepercayaan 95 persen dan memiliki nilai probabilitas 0,000000 lebih kecil dari $\alpha$ $(0,05)$. Berdasarkan hasil perhitungan tersebut maka dapat disimpulkan bahwa $\mathrm{H} 0$ ditolak dan koefisien regresi signifikan secara statistik.

3. Hasil Uji Hipotesis Secara Parsial (Uji t) Dengan asumsi terima $\mathrm{H} 0$ jika thitung $<$ ttabel atau tolak H0 jika thitung > ttabel atau dengan melihat perbandingan probabilitasnya $\quad(\operatorname{sig}<\alpha) \quad$ berdasarkan hipotesis. Hasil Uji t dalam penelitian ini dapat dilihat pada tabel berikut:

Tabel 8. Hasil uji t

\begin{tabular}{|clcc|} 
No & \multicolumn{1}{c}{ Variabelbebs } & \$n1. & Probabilitas \\
\hline 1 & Produksi beras $\left(\mathrm{X}_{1}\right)$ & $-3.077184^{*}$ & 0.0088 \\
\hline 2 & Konsumsi beras $\left(\mathrm{X}_{2}\right)$ & $6.210970^{*}$ & 0.0000 \\
3 & Harga beras irmor $\left(\mathrm{X}_{3}\right)$ & $0.119409^{*}$ & 0.9068 \\
4 & Nilai tukar mupiah $\left(\mathrm{X}_{4}\right)$ & $1.953459^{*}$ & 0.0726
\end{tabular}

Sumber: Data sekunder diolah, 2015.

Pada tingkat kepercayaan $90 \%$ didapat ttabel sebesar 1,35. Nilai ttabel diperoleh dari nilai degree of freedom (df) sebesar n-k (18$5=13$ ) dengan tingkat signifikansi $10 \%$ yakni sebesar 1,35 . Untuk variabel pertama yaitu produksi beras (X1) thitung bernilai 3.077184 dan lebih besar dari ttabel yaitu 1,35 serta memiliki nilai prob. lebih kecil dari nilai $\alpha(0.0088<0,1)$. Hal ini dapat dikatakan 
bahwa H0 ditolak dan koefisien produksi beras signifikan secara statistik. Sehingga dapat disimpulkan bahwa variabel produksi beras domestik memiliki pengaruh yang negatif dan signifikan pada tingkat signifikan $10 \%$ terhadap harga beras di Indonesia.

Variabel kedua yaitu konsumsi beras (X2), nilai thitung bernilai 6.210970 berarti lebih besar dari ttabel $(1,350)$ pada tingkat kepercayaan $90 \%$ serta memiliki nilai signifikansi lebih kecil dari nilai $\alpha(0.0000<$ $0,1)$. Hal ini dapat dikatakan bahwa HO ditolak dan koefisien konsumsi beras signifikan secara statistik pada tingkat kepercayaan $90 \%$. Sehingga dapat disimpulkan bahwa variabel konsumsi beras domestik memiliki pengaruh yang positif dan signifikan pada tingkat signifikan 10\% terhadap harga beras di Indonesia.

Variabel ketiga yaitu harga beras impor (X3), nilai thitung bernilai 0.119409 berarti lebih kecil dari ttabel $(1,35)$ pada tingkat kepercayaan $90 \%$ serta memiliki nilai signifikansi lebih besar dari nilai $\alpha(0.9068>$ 0,1). Hal ini dapat dikatakan bahwa $\mathrm{HO}$ diterima dan koefisien konsumsi beras tidak signifikan secara statistik pada tingkat kepercayaan $90 \%$. Sehingga dapat disimpulkan bahwa variabel harga beras impor memiliki pengaruh yang positif dan tidak signifikan pada tingkat signifikan $10 \%$ terhadap harga beras di Indonesia.

Variabel keempat yaitu nilai tukar rupiah (X4), nilai thitung bernilai 1.953459 berarti lebih besar dari ttabel $(1,35)$ pada tingkat kepercayaan $90 \%$ serta memiliki nilai signifikansi lebih kecil dari nilai $\alpha(0.0726<$ $0,1)$. Hal ini dapat dikatakan bahwa $\mathrm{H} 0$ ditolak dan koefisien nilai tukar rupiah signifikan secara statistik pada tingkat kepercayaan 90\%. Sehingga dapat disimpulkan bahwa variabel nilai tukar rupiah terhadap dollar Amerika memiliki pengaruh yang positif dan signifikan pada tingkat signifikan $10 \%$ terhadap harga beras di Indonesia.
Sehingga dapat disimpulkan bahwa dalam pengujian pengaruh setiap variabel independen seperti produksi beras domestik, konsumsi beras domestik, dan nilai tukar rupiah terhadap dollar Amerika berpengaruh secara nyata terhadap variabel dependennya yaitu harga beras domestik. Sedangkan variabel harga beras impor berpengaruh secara tidak nyata terhadap variabel dependennya yaitu harga beras domestik.

\section{KESIMPULAN}

Berdasarkan dari hasil penelitian yang dilakukan terhadap faktor-faktor yang mempengaruhi pembentukan harga beras di Indonesia tahun 1996-2013 didapatkan kesimpulan sebagai berikut :

1 Komoditas beras di Indonesia merupakan komoditas pangan yang mendapat proteksi dari pemerintah. Harga beras yang terbentuk di pasar domestik tidak terlepas dari proses mekanisme pasar yang dipengaruhi oleh kekuatan supply dan demand. Harga beras yang terbentuk dari proses mekanisme pasar tersebut pun pada akhirnya ditentukan oleh pemerintah yakni berupa penetapan kebijakan ceiling price (harga atap) di tingkat konsumen.

2 Variasi yang terjadi pada produksi beras domestik, konsumsi beras domestik, harga beras impor dan nilai tukar rupiah terhadap dollar dapat menjelaskan pembentukan harga beras sebesar 90,76\%. Dari keseluruhan variabel bebas yaitu produksi beras domestik, konsumsi beras domestik, harga beras impor dan nilai tukar rupiah terhadap dollar secara serempak memberikan pengaruh yang sangat signifikan. Secara parsial menunjukkan bahwa variabel produksi beras domestik, konsumsi beras domestik dan nilai tukar rupiah terhadap dollar Amerika 
memberikan pengaruh yang nyata terhadap harga beras domestik sedangkan variabel harga beras impor menunjukkan pengaruh tidak nyata terhadap harga beras domestik.

\section{SARAN}

Saran yang dapat penulis berikan berdasarkan penelitian yang telah dilakukan adalah :

1 Program swasembada beras perlu dialihkan menjadi program swasembada kabohidrat yakni dengan mengembalikan kebiasaan mengkonsumsi beras ke bahan pangan lokal di setiap masing-masing daerah di Indonesia. hal ini dikarenakan anggaran yang dikeluarkan oleh negara untuk melindungi komoditas beras dari ketidakstabilan akan semakin membengkak karena dalam memproduksinya diperlukan dana yang besar dan jumlah kebutuhan beras yang terus meningkat setiap tahunnya.

2 Bagi peneliti yang akan menindaklanjuti penelitian ini disarankan untuk menambahkan variabel lainnya atau variabel dummy serta rentang waktu yang diteliti dapat ditambahkan dan dibedakan berdasarkan era kepemimpinan yaitu pada era orde lama, baru dan reformasi sehingga dapat dibandingkan efektifitas kondisi ekonomi perberasan.

\section{DAFTAR PUSTAKA}

Anonim. 2010. Kinerja Perdagangan Komoditas Pertanian Volume 2 Nomor 1

Tahun 2010. Pusat Data dan Informasi Pertanian, Kementerian Pertanian. Jakarta.
Ariefianto, Doddy. 2012. Ekonometrika Esensi dan Aplikasi dengan

Menggunakan Eviews. Erlangga. Jakarta.

Arifin, Bustanul. 2007. Diagnosis Ekonomi Politik Pangan dan Pertanian. PT Rajagrafindo Persada. Jakarta.

------. 2013.Ekonomi Pembangunan Pertanian. PT Penerbit IPB Press. Bogor.

Firdaus, Muhammad, dkk. 2008. Swasembada Beras dari Masa ke Masa Telaah

Efektivitas Kebijakan dan Perumusan Strategi Nasional. IPB Press. Bogor.

Gilarso, T. 2003. Pengantar Ilmu Ekonomi Mikro Edisi Revisi. Kanisius. Yogyakarta.

Hessie, Rethna. 2009. Analisis Produksi dan Konsumsi Beras dalam Negeri serta Implikasinya terhadap Swasembada Beras di Indonesia. [Skripsi]. Institut Pertanian Bogor. Bogor.

Isma'il, Nur Mahmudi. 2014. Revolusi Mindset: One Day No Rice Untuk

Indonesia Sehat dan Sejahtera. Gema Insani. Jakarta.

Litbang. 2005. Prospek dan Arah Pengembangan Agribisnis: Dukungan Aspek

Teknologi Pascapanen. Badan Litbang Pertanian. Jakarta.

Malian, A. Husni, dkk. 2004. Faktor-faktor yang Mempengaruhi Produksi, Konsumsi dan Harga Beras serta Inflasi Bahan Makanan. Pusat 
Penelitian dan Pengembangan Sosial Ekonomi Pertanian. Bogor.

Murni, Asfia dan Lia Amaliawati. 2013. Ekonomika Mikro. PT Refika Aditama.Bandung.

Nachrowi, D Nachrowi dan Hardius Usman. 2006. Pendekatan Populer dan Praktis Ekonometrika Untuk Analisis Ekonomi dan Keuangan. Lembaga Penerbit Fakultas Ekonomi Universitas Indonesia. Jakarta.

Nopirin. 2014. Ekonomi Internasional Edisi 3. BPFE-Yogyakarta. Yogyakarta.

------. 2014. Pengantar Ilmu Ekonomi Makro \& Mikro; Edisi Pertama. BPFE- Yogyakarta. Yogyakarta.

Pindyck, Robert S. dan Daniel L. Rubinfeld. 2014. Mikroekonomi Edisi Kedelapan. Penerbit Erlangga. Jakarta.

Pracoyo, Tri Kunawangsih dan Antyo Pracoyo. 2006. Aspek Dasar Ekonomi Mikro. PT Grasindo. Jakarta.

Prastowo, Nugroho Joko, dkk. 2008. Pengaruh Distribusi dalam Pembentukan Harga Komoditas dan Implikasinya terhadap Inflasi. Bank Indonesia. Jakarta.

Putong, Iskandar. 2013. Economics Pengantar Mikro dan Makro Edisi 5. Mitra Wacana Media. Jakarta.

Rahardja, Prathama dan Mandala Manurung. 2008. Teori Ekonomi Makro Suatu Pengantar Edisi Keempat Buku Seri Teori Ekonomi. Lembaga Penerbit
Fakultas Ekonomi Universitas Indonesia. Jakarta.

2010. Teori Ekonomi Mikro Suatu Pengantar Edisi Keempat Buku Seri Teori Ekonomi. Lembaga Penerbit Fakultas Ekonomi Universitas Indonesia. Jakarta.

Rusono, Nono, dkk. 2013. Studi Pendahuluan: Rencana Pembangunan Jangka Menengah Nasional (RPJMN) Bidang Pangan dan Pertanian 2015-2019. Direktorat Pangan dan Pertanian, Bappenas. Jakarta.

Saliem, Handewi Purwati, dkk. 2005. Manajemen Ketahanan Pangan Era Otonomi Daerah dan Perum Bulog. Pusat Analisis Sosial Ekonomi dan Kebijakan Pertanian. Bogor.

Sawit, M. Husein. 2007. Usulan Kebijakan Beras dari Bank Dunia: Resep yang

Keliru. Pusat Analisis Sosial Ekonomi dan Kebijakan Pertanian. Bogor.

------. 2007. Liberalisasi Pangan: Ambisi dan Reaksi dalam Putaran Doha WTO.

Lembaga Penerbit Fakultas Ekonomi, Uniersitas Indonesia. Jakarta.

------. 2001. Kebijakan Harga Beras: Periode Orba dan Reformasi dalam Bunga

Rampai Ekonomi Beras. LPEM-FEUI. Jakarta.

Sugiharto, Hari Nugroho. 2011. Analisis Faktor-faktor yang Mempengaruhi Harga Beras di Indonesia Tahun 
1988-2008. [Skripsi] Universitas Muhammadiyah Surakarta. Surakarta.

Sugiyono. 2013. Metode Penelitian Kuantitatif Kualitatif dan $R \& D$. Alfabeta. Bandung.

Sukirno, Sadono. 2014. Mikroekonomi Teori Pengantar Edisi Ketiga. PT RajaGrafindo Persada. Jakarta.

Suryana, Achmad, dkk. 2005. Prospek dan Arah Pengembangan Agribisnis Padi. Badan Litbang Pertanian. Jakarta.

Trubus exo. 2013. Kiat Tingkatkan Produksi Padi. Trubus. Jakarta.

Widadie, Fanny dan Adi Susanto. 2012. Model Ekonomi Perberasan: Analisis
Integrasi Pasar dan Simulasi Kebijakan Harga. SEPA: Vol. 8 No. 2.

Widarjono, Agus. 2013. Ekonometrika Pengantar dan Aplikasinya Edisi Keempat.

UPP STIM YKPN. Yogyakarta. Widodo, Sri. 2012. Politik Pertanian. Liberty. Yogyakarta.

Winarno, Wing Wahyu. 2011. Analisis Ekonometrika dan Statistika dengan Eviews Edisi 3. UPP STIM YKPN. Yogyakarta.

* Alamat korespondensi: edmon.daris@uinjkt.ac.id 